\title{
Nordic - India Cooperation in Developing Sustainable Cities
}

\author{
Enrico Nataniel \\ Parahyangan Catholic University \\ enriconataniel@yahoo.com
}

\begin{abstract}
Urbanisasi merupakan salah satu permasalahan sosial berkelanjutan yang masih terjadi hingga dewasa ini, dimana $66 \%$ dari penduduk dunia diproyeksikan akan hidup di perkotaan pada tahun 2050. Hal ini menjadi tantangan bagi aktor negara maupun non-negara dalam mengatasi masalah-masalah perkotaan. Masalah tersebut dapat berupa kesenjangan sosial, kemiskinan, kriminalitas, kerusakan lingkungan, dan lain-lain. Oleh karena itu, paper ini bertujuan untuk menjelaskan mengenai tujuan ke-11 dari Tujuan Pembangunan Berkelanjutan (SDGs) terkait dengan sustainable cities and communities yang tentunya berkaitan erat dengan persoalan urbanisasi. Pada paper ini, contoh negara yang dianalisis adalah India sebagai negara yang memiliki persoalan urban yang serius. Selain itu, negara-negara Skandinavia sebagai salah satu pengembang dari program kota berkelanjutan juga menjadi objek analisis pada paper ini dimana pada saat ini mereka sedang melakukan kerjasama dengan India dalam pemenuhan tujuan ke-11 tersebut. Kerjasama ini tentunya melibatkan aktor-aktor negara, disertai dengan aktor-aktor nonnegara seperti perusahaan multinasional. Pada paper ini, penulis menggunakan metode kualitatif dengan melakukan kajian baik terhadap literatur, publikasi, maupun berita terkait dengan program kota berkelanjutan negara-negara Skandinavia serta kerjasama antara negara Skandinavia dengan India terkait dengan program yang bersangkutan. Penulis juga akan menggunakan Green Theory dalam melakukan analisis mengenai SDGs dan juga Nordic Sustainable Cities. Melalui penulisan ini, besar harapan penulis agar negara-negara lain dapat mengikuti jejak negara-negara Skandinavia dalam pemenuhan salah satu tujuan dari SDGs yaitu sustainable cities and communities.
\end{abstract}

Keywords: Urbanization, Scandinavian Countries, India, Sustainable Cities, Green Theory

\section{Background}

Urbanization has been a global issue for decades since it causes rapid population growth in the urban areas. According to the United Nations, 4.2 billion of people lived in cities by 2018 which is about 55 percent of world population. ${ }^{1}$ It is projected that by 2050,66 percent of global population which is approximately 6.5 billion people - are going to live in the urban areas mainly in African and

\footnotetext{
${ }^{1}$ United Nations Development Programme, "Goal 11: sustainable cities and communities," https://www.undp.org/content/undp/en/home/sustainable-development-goals/goal-11-sustainable-cities-andcommunities.html, accessed on $12^{\text {th }}$ March 2020
} 
Asian cities. ${ }^{2}$ Lots of people in the world are moving to bigger cities mainly due to economic reason. However, it causes more urban issues such as poverty, crimes, unemployment, environmental damages, etc.

India is one of the countries which has serious urban issue due to urbanization and high population density. The population of Mumbai, which is the biggest city in India, was around 18 million people in $2011 .^{3}$ Moreover, it is projected that the city currently has more than 20 million people. ${ }^{4}$ Mumbai is also one of the most densely populated cities in the world which is 76,790 people per square mile. ${ }^{5}$ Many urban areas in India are also filled by slums where the housing quality is low and the living quality is extremely poor. According to the World Bank, slum population in India was about 41 million in $2001 .{ }^{6}$ Therefore, it is projected that the current slum population is about 70 million. Compared with the total population of India - which is about 1.3 billion - the number of slum population is relatively small. However, it can't be refuted that 70 million is not a small number.

In order to solve such issues, the United Nations Development Program (UNDP) has been working to make cities in the whole world more sustainable through the Sustainable Development Goals (SDGs) specifically goal number eleven regarding sustainable cities and communities. Following the creation of the SDGs, several state and non-state actors initiated a program to promote the idea of sustainable cities as an effort to fulfill goal number eleven. Nordic Countries such as Denmark, Sweden, Norway, Iceland, and Finland are the primary examples of the state actors who are currently developing a global initiative to promote sustainable cities. As an example, Copenhagen - which is the capital city of Denmark - had been planning to reduce carbon emission by $20 \%$ since 2005 until $2015 .^{7}$ The city is currently working to achieve carbon neutrality by 2025 . On the other hand, Oslo - which is the capital city of Norway - currently has a 'car-free city center' since 2019 which is intended to make the city more welcoming, more connected, and most importantly greener. ${ }^{8}$

\footnotetext{
${ }^{2}$ L.A. Borges, et.al., White Paper on Nordic Sustainable Cities Developed by Nordregio (Stockholm: Nordregio, 2017), 7.

${ }^{3}$ Press Information Bureau, "India Stats: Million plus cities in India as per Census 2011," http://pibmumbai.gov.in/scripts/detail.asp?releaseId=E2011IS3, 31 $1^{\text {st }}$ October 2011, accessed on $12^{\text {th }}$ March 2020

${ }^{4}$ World Population Review, "Mumbai Population 2020," https://worldpopulationreview.com/worldcities/mumbai-population/, accessed on $12^{\text {th }}$ March 2020.

${ }^{5}$ Elzy Kolb, "75,000 people per square mile? These are the most densely populated cities in the world," USA Today, https://www.usatoday.com/story/news/world/2019/07/11/the-50-most-densely-populated-cities-in-theworld/39664259/, $11^{\text {th }}$ July 2019 , accessed on $12^{\text {th }}$ March 2020.

${ }^{6}$ The World Bank, "India's Urban Challenges," https://www.worldbank.org/en/news/feature/2011/07/04/indiasurban-challenges, $14^{\text {th }}$ July 2011, accessed on $12^{\text {th }}$ March 2020.

${ }^{7}$ Ibid.

${ }^{8}$ Sarah Shemkus, "In Norway, Oslo leaders are creating a 'car-free city center.' Could Boston be Next?," Energy News Network, https://energynews.us/2019/07/15/northeast/in-norway-oslo-leaders-are-creating-a-carfree-city-center-could-boston-be-next/, $15^{\text {th }}$ July 2019, accessed on $12^{\text {th }}$ March 2020.
} 
According to Nordregio - an international research center which promote the idea of Nordic Sustainable Cities - there are several types of sustainable city such as inclusive city, healthy city, resilient city, compact green city, mobility city, low carbon city, circular economy city, smart city, and design city. ${ }^{9}$ These themes were being promoted during exhibition in Copenhagen, and some other cities outside Nordic Region such as Kiev and Santiago in order to convince people outside the region how sustainable are Nordic cities. Furthermore, they are currently cooperating with India - which has a serious urban issue - to fulfill the eleventh goal of the SDGs by implementing Nordic Sustainable Cities in a global scale.

\section{Theoretical Approaches}

There is one theoretical approach as the basic of this paper writing which is Green Theory. Green theory challenges the existing political, social, and economic structure - especially mainstream liberal political and economic assumptions. ${ }^{10}$ This theory believes that human development should be concerned with preserving non-human nature by limiting our freedom to consume. Unlike traditional IR theories - which are concerned on states - green theory promotes a concept called ecocentrism which focuses on ecology. Although ecocentrism stands against anthropocentrism (human-centered thought), that does not mean this theory ignores human needs and desires. It prioritizes on healthy ecosystem which is good for human's health and wellbeing. Ecocentrism tends rejects boundaries between domestic and international affair since it is believed that environmental issues such as air pollution, water contamination, and climate change might affect human population in a global scale. ${ }^{11}$ Therefore, a global solution is necessary in order to solve global environmental issues.

\section{The Implementation of Goal Number Eleven by Nordic Countries in India}

Following the creation of the United Nations, several programmes were created to develop global cooperation between nation-states in some aspects. One of the well-known programmes is called United Nations Development Programme (UNDP). This programme focuses on achieving the Millennium Development Goals (MDGs) - which is currently known as the Sustainable Development Goals (SDGs) - by coordinating cooperation among nation-states. The SDGs contain seventeen goals, and one of them is sustainable cities and communities which is goal number eleven. The goal was created due to the wave of urbanization which cause a lot of urban issues such as poverty,

\footnotetext{
${ }^{9}$ L.A. Borges, et.al., What makes a sustainable city? (Oslo: Nordic Innovation, 2017), 4-30.

${ }^{10}$ Hugh Dyer, "Introducing Green Theory in International Relations," E-International Relations (2018): 2.

${ }^{11}$ Ibid.
} 
unemployment, and environmental damage. It is also projected by the United Nations that approximately 6.5 billion people are going to live in urban areas in 2050. Thus, the aim of goal number eleven is to make cities and human settlements inclusive, safe, resilient, and sustainable. ${ }^{12}$

Several member states of the United Nations are currently implementing the goal by creating their own sustainable cities and promoting the idea in a global scale. Scandinavian countries such as Denmark, Norway, Sweden, Finland, and Iceland created their own sustainable cities for themselves such as reducing carbon emission and creating car-free zones in Copenhagen and Oslo. Furthermore, they initiated a project called Nordic Sustainable Cities, and they cooperated with some other countries outside Nordic Region - especially with India - in order to implement goal number eleven of the SDGs.

It is believed that poor urban management in India is the main cause of low quality of life in urban areas even though the Government of India has attempted to solve their urban issues for more than a decade. In 2009, finance minister Pranab Mukherjee - who served under Prime Minister Singh's administration - allocated Rs40bn (\$850m) for spending on housing and basic services. ${ }^{13}$ The spending itself was aimed to improve city infrastructure and also to make the country "slum free". Furthermore, in 2015, India under the administration of Prime Minister Narendra Modi started a programme called Indian Smart Cities Mission which focuses on developing 100 cities around the country to make cities more technologically developed, safer for citizens, better electricity and water supply, and environmentally sustainable. ${ }^{14}$ India also has cooperated with some other countries to develop their urban planning mainly with Nordic Countries.

India has already had bilateral ties with Nordic Countries for a long time - not very long after India gained independence in 1948. However, the relation between India and Nordic Countries were not as close as these recent years. The relation between them is developing due to the First India Nordic Summit regarding economic and security cooperation in 2018 which was hosted by the Prime Minister of Sweden Stefan Löfven and Prime Minister of India Narendra Modi. ${ }^{15}$ The summit was held in Stockholm which was attended by the Prime Minister of India and the Prime Ministers of Nordic

\footnotetext{
${ }^{12}$ United Nations, "Goal 11: Make cities inclusive, safe, resilient, and sustainable," https://www.un.org/sustainabledevelopment/cities/\#: :text=Goal\%2011\%3A\%20Make\%20cities\%20inclusive $\% 2 \mathrm{C} \% 20 \mathrm{safe} \% 2 \mathrm{C} \% 20$ resilient $\% 20$ and $\% 20$ sustainable \&text=Cities\%20are\%20hubs\%20for\%20ideas,social\%2 Odevelopment\%20and\%20much\%20more., accessed on $12^{\text {th }}$ March 2020.

${ }^{13}$ James Lamont, "India's five year plan to clear slums," Financial Times, https://www.ft.com/content/bfdf6948-6c8a-11de-a6e6-00144feabdc0, $9^{\text {th }}$ July 2009, accessed on $12^{\text {th }}$ March 2020.

${ }^{14}$ Ministry of Urban Development, Smart Cities Mission Statement \& Guidelines (New Delhi: Government of India, 2015), 5-6.

${ }^{15}$ Dipanjan Roy Chaudhury, "First India-Nordic Summit calls for free trade and rules based on global order," The Economic Times, https://economictimes.indiatimes.com/news/politics-and-nation/first-india-nordicsummit-calls-for-free-trade-and-rules-based-global-order/articleshow/63808071.cms, $18^{\text {th }}$ April 2018, accessed on $12^{\text {th }}$ March 2020
} 
Countries. Beside economic and security cooperation, Nordic Sustainable Cities Project was also discussed in the summit in order to support Indian Smart Cities Program.

Some cities in India are being targeted by this project. The first one is Panaji which is the capital city of Goa State. Nordic Prime Ministers' initiatives which is known as Nordic Solution to Global Challenge took part in implementing goal number eleven regarding sustainable cities and communities in Panaji by funding an Indian Urban Lab in the city. ${ }^{16}$ Panaji itself also has a programme called The Imagine Panaji Smart City which is helped by Denmark. Although this cooperation is more focused on technological development, environmental aspect is not ignored. With the support of Denmark through government spending, Panaji created its own sustainable city by installing about 460 CCTV cameras for many reasons, and one of the reasons is to watch garbage dumping in the city. ${ }^{17}$ This programme also includes waste and environmental management systems which is highly concerned with the environment of the city as an implementation of goal number eleven to make Panaji sustainable for living. Thus, this programme can be described as ecocentric since it is pretty concerned with the environmental aspect beside technological aspect. However, this programme does not put Panaji's environment above its citizens since an environmentally healthy city is believed to bring positive affect for its citizens such as better health and quality of life.

The second one is a city called Gurgaon which is located in Haryana State near New Delhi. Gurgaon is one of the leading financial centres in India, and the city is also well-known for the establishment of leading Indian automobile manufacturer Maruti Suzuki India Limited. ${ }^{18}$ Despite its economic development, Gurgaon was also listed as one of the most polluted cities by Air Visual and Greenpeace in 2019. ${ }^{19}$ In order to solve the environmental crisis, Sweden helped India to make Gurgaon a climate-neutral city. The cooperation began when M3M - an Indian based company - signed an agreement with Sweco - a Swedish engineering consultancy company - to develop a smart city in Gurgaon. The agreement was signed during India-Sweden Business Leaders Roundtable which is attended by the King of Sweden Carl XVI Gustaf. This cooperation focuses on climate resilience, mitigation, water conservation, reusability, and waste recycling as an implementation of the UN

\footnotetext{
${ }^{16}$ Akita Dutta, "Issues of Cooperation in India-Nordic Relations," Indian Council of World Affairs, https://www.icwa.in/show_content.php?lang=1\&level=3\&ls_id=3642\&lid=2841, $1^{\text {st }}$ November 2018, accessed on $12^{\text {th }}$ March 2020.

${ }^{17}$ NT Network, "Panaji set to get "urban city lab'," The Navhind Times, http://www.navhindtimes.in/panaji-setto-get-urban-living-lab/, $23^{\text {rd }}$ January 2019, accessed on $12^{\text {th }}$ March 2020.

${ }^{18}$ Government of India, "About District," https://gurugram.gov.in/about-district/, accessed on 12 $2^{\text {th }}$ March 2020.

${ }^{19}$ Nick Van Mead, "22 of world's 30 most polluted cities are in India, Greenpeace says," The Guardian, https://www.theguardian.com/cities/2019/mar/05/india-home-to-22-of-worlds-30-most-polluted-citiesgreenpeace-says, $5^{\text {th }}$ March 2019, accessed on $12^{\text {th }}$ March 2020.
} 
Sustainable Development Goals and Paris Agreement regarding climate issues. ${ }^{20}$ Similar with the previous programme in the city of Panaji, this programme is also highly concerned with the environment of Gurgaon due to high level of pollution in the city which means this programme can be described as ecocentric as well. As mentioned above, ecocentrism is not only concerned with the environment of the city, but also the citizens since this programme is projected to make the city cleaner, healthier, and safer for the citizens. Thus, this programme is also expected to deliver a better health and quality of life for the people of Gurgaon.

\section{Conclusion}

Based on green theory, the cooperation between India and Scandinavian countries can be described as ecocentric since it is highly concerned with urban environment. Although Scandinavian countries are not geographically close to India, it is believed that environmental issue is a global issue which requires global solution. As an example, air and water pollution in Indian urban areas might also affect human population from the other parts of the world which means urban issues in India require global solution. Moreover, the human aspect is not ignored in the process of implementing goal number eleven in India since a healthy and sustainable city is created for the interests and needs of the people in India - mainly those who live in urban areas. Thus, it is highly expected that this cooperation delivers a better quality of life and safety for the people living in Indian urban areas such as the people of Panaji and Gurgaon.

\footnotetext{
${ }^{20}$ Faizan Haidar, "Sweden to help India in building climate neutral smart city," The Economic Times, https://economictimes.indiatimes.com/news/economy/infrastructure/sweden-to-help-india-in-building-climateneutral-smart-city/articleshow/72353422.cms?from $=$ mdr, $3^{\text {rd }}$ December 2019, accessed on $12^{\text {th }}$ March 2020.
} 


\section{References}

Borges, L.A. et.al. What makes a sustainable city?. Oslo: Nordic Innovation, 2017.

Borges, L.A., et.al. White Paper on Nordic Sustainable Cities Developed by Nordregio. Stockholm: Nordregio, 2017.

Chaudhury, Dipanjan Roy. "First India-Nordic Summit calls for free trade and rules based on global order". The Economic Times. https://economictimes.indiatimes.com/news/politics-andnation/first-india-nordic-summit-calls-for-free-trade-and-rules-based-globalorder/articleshow/63808071.cms, 2018.

Dutta, Akita. "Issues of Cooperation in India-Nordic Relations". Indian Council of World Affairs, https://www.icwa.in/show_content.php?lang=1\&level=3\&ls_id=3642\&lid=2841, 2018.

Dyer, Hugh. "Introducing Green Theory in International Relations". E-International Relations (2018): 2.

Government of India. “About District”. https://gurugram.gov.in/about-district/.

Haidar, Faizan. "Sweden to help India in building climate neutral smart city". The Economic Times. https://economictimes.indiatimes.com/news/economy/infrastructure/sweden-to-help-india-inbuilding-climate-neutral-smart-city/articleshow/72353422.cms?from=mdr, 2019.

Kolb, Elzy. "75,000 people per square mile? These are the most densely populated cities in the world". USA Today. https://www.usatoday.com/story/news/world/2019/07/11/the-50-most-denselypopulated-cities-in-the-world/39664259/, 2019.

Lamont, James. "India's five year plan to clear slums". Financial Times. https://www.ft.com/content/bfdf6948-6c8a-11de-a6e6-00144feabdc0, 2009.

Ministry of Urban Development. Smart Cities Mission Statement \& Guidelines. New Delhi: Government of India, 2015.

NT Network. "Panaji set to get "urban city lab". The Navhind Times. http://www.navhindtimes.in/panaji-set-to-get-urban-living-lab/, 2019. 
Press Information Bureau. "India Stats: Million plus cities in India as per Census 2011". http://pibmumbai.gov.in/scripts/detail.asp?releaseId=E2011IS3, 2011.

Shemkus, Sarah. “In Norway, Oslo leaders are creating a 'car-free city center.' Could Boston be Next?”. Energy News Network. https://energynews.us/2019/07/15/northeast/in-norway-oslo-leadersare-creating-a-car-free-city-center-could-boston-be-next/, 2019.

The

$$
\text { World }
$$

Bank.

"India's

Urban

Challenges". https://www.worldbank.org/en/news/feature/2011/07/04/indias-urban-challenges, 2011.

United Nations. "Goal 11: Make cities inclusive, safe, resilient, and sustainable". https://www.un.org/sustainabledevelopment/cities/\#: :text=Goal\%2011\%3A\%20Make\%20ci ties\%20inclusive $\% 2 \mathrm{C} \% 20$ safe $\% 2 \mathrm{C} \% 20$ resilient $\% 20$ and $\% 20$ sustainable\&text=Cities\%20are $\% 20$ hubs\%20for\%20ideas,social\%20development\%20and\%20much\%20more.

United Nations Development Programme. "Goal 11: sustainable cities and communities". https://www.undp.org/content/undp/en/home/sustainable-development-goals/goal-11sustainable-cities-and-communities.html.

Van Mead, Nick. "22 of world's 30 most polluted cities are in India, Greenpeace says," The Guardian, https://www.theguardian.com/cities/2019/mar/05/india-home-to-22-of-worlds-30-mostpolluted-cities-greenpeace-says, 2019.

World Population Review. "Mumbai Population 2020". https://worldpopulationreview.com/worldcities/mumbai-population/. 